\title{
Potential Treatment Approaches to SARS-CoV-2 and Evaluation of Drug Carrier Systems in Treatment
}

\section{SARS-CoV-2'ye Yönelik Potansiyel Tedavi Yaklaşımları ve İlaç Taşıyıcı Sistemlerin Tedavide Değerlendirilmesi}

\author{
(i) Sema ARISOY1, iD Tansel ÇOMOĞLU22 \\ Iİnönü University Faculty of Pharmacy, Department of Pharmaceutical Biotechnology, Malatya, Turkey \\ ${ }^{2}$ Ankara University Faculty of Pharmacy, Department of Pharmaceutical Technology, Ankara, Turkey
}

\begin{abstract}
The severe acute respiratory syndrome-coronaviruse-2 (SARS$\mathrm{CoV}-2)$ genome is packaged in a helical nucleocapsid surrounded by a lipid bilayer. The virus envelope contains at least three viral proteins called spike protein $(S)$, membrane protein $(M)$ and envelope protein (E). While $\mathrm{M}$ and $\mathrm{E}$ form the structure of the virus, $S$ protein is the leading agent of the entry of viruses into the host. Angiotensin converting enzyme-2 (ACE-2) has been identified as a functional receptor for coronaviruses, including SARS-CoV and SARS-CoV-2. Viral fusion is the main step in the onset of SARS-CoV-2 infection. It is thought that drugs that prevent spike protein and ACE-2 fusion, drugs acting on the renin-angiotensinaldesterone system, and a high dose ACE- 2 can act on this fusion mechanism and take part in COVID-19 treatment. In this context, especially nano-sized liposomal carriers attract attention due to their biocompatibility and cell-like structures in the treatment of infectious diseases. There are studies in which liposomes are also used as a secondary therapeutic to support traditional anti-infective drugs. In this review, therapeutic approaches that may reduce and treat the severity of the disease by preventing ACE- 2 mediated entry of viruses are discussed.
\end{abstract}

Keywords: COVID-19, SARS-CoV-2, liposomes, COVID-19 treatment

\section{ÖZ}

Şiddetli akut solunum yolu enfeksiyonu sendromu-koronavirüs-2 (SARS-CoV-2) genomu, lipit çift tabakası ile çevrelenen sarmal bir nükleokapsid içine paketlenmiştir. Virüs zarfı, spike proteini (S), zar proteini $(\mathrm{M})$ ve zarf proteini (E) olarak isimlendirilen en az üç viral protein içermektedir. $M$ ve $E$ virüsün yapısını oluştururken, $S$ proteini virüslerin konakçıya girişinin önde gelen aracısıdır. Anjiyotensin dönüştürücü enzim-2 (ACE-2), SARS-CoV ve SARS-CoV-2 dahil koronavirüsler için fonksiyonel bir reseptör olarak tanımlanmıştır. Viral füzyon SARS-CoV-2 enfeksiyonunun başlangıcında temel adımı oluşturmaktadır. Spike protein ve ACE2 füzyonunu engelleyen ilaçların, renin-anjiyotensin-aldesteron sistemi üzerine etki eden ilaçların ve ekses dozda ACE-2'nin bu füzyon mekanizması üzerine etki ederek COVİD-19 tedaviside yer alabileceği düşünülmüştür. Bu bağlamda özellikle nanoboyutlu lipozomal taşıyıcılar, enfeksiyöz hastalıkların tedavisinde biyo-uyumlulukları ve hücreye benzer yapıları nedeniyle dikkat çekmektedir. Lipozomların geleneksel anti-enfektif ilaçları desteklemek için ikincil bir terapötik olarak da kullanıldığ çalışmalar bulunmaktadır. Bu derlemede virüslerin ACE-2 aracılı girişini engelleyerek hastalığın şiddetini azaltma ve tedavi etme ihtimali olan terapötik yaklaşımlar ele alınmıştır.

Anahtar Sözcükler: COVID-19, SARS-CoV-2, lipozomlar, COVİD-19 tedavisi
Address for Correspondence: Tansel ÇOMOĞLU, Ankara University Faculty of Pharmacy, Department of Pharmaceutical Technology, Ankara, Turkey

E-mail: comoglu@pharmacy.ankara.edu.tr ORCID ID: orcid.org/0000-0002-4221-5814
Received: 06.07.2020

Accepted: 04.08 .2020

Cite this article as: Arısoy S, Çomoğlı T. Potential Treatment Approaches to SARS-CoV-2 and Evaluation of Drug Carrier Systems in Treatment. Bezmialem Science 2020;8(Supplement 3):117-25. 


\section{Introduction}

Coronaviruses (CoVs) are enveloped, positively charged singlestranded RNA viruses that can cause infection in humans and animals. In 2003, the highly pathogenic and severe respiratory infection virus, called severe acute respiratory syndrome (SARS) virus (SARS-CoV), emerged in China and spread rapidly around the world. On December 29, 2019 Symptoms of lung infection (pneumonia) developed in four people working in a market selling seafood and live animals and other people who visited the same market on the same days in Wuhan, China. Later on researches showed that the cause of the infections was from a newly introduced coronavirus species. This virus has been named the new Coronavirus-2019 (COVID-19) (2). Later, it was officially named SARS-CoV-2 by the World Health Organization (WHO) (3). CoVs are enveloped, globular or polymorphic viruses ranging in size from $80-120 \mathrm{~nm}$. It has a 5' capped, single stranded positively charged RNA genome, with 26.2-1.7 kb in size and is the longest of all RNA viruses. CoVs present a crown appearance under electron microscopy due to the presence of pin-like glycoproteins on the lipid envelope. For this reason, it was named "corona", which means crown in Latin (4).

There are four classes of CoVs called alpha, beta, gamma, and delta (5). Genomic characterization studies show that alphaCoV and betaCoVs originate from bat and rodents. Members of this virus family cause respiratory, enteric, hepatic, and neurological diseases in different animal species, including camels, cattle, cats and bats. To date, seven human $\mathrm{CoV}(\mathrm{HCoV})$ that can infect humans have been identified. Some $\mathrm{HCoVs}$ were detected in the mid-1960s, others more recently. Studies show that HCoVs causes common cold mainly during winter with $4 \%-15 \%$ prevalence. These viruses are $\mathrm{HCoV}-\mathrm{OC} 43, \mathrm{HCoV}-\mathrm{HKU} 1$, $\mathrm{HCoV}-229 \mathrm{E}$ and HCoV-NL63. While these viruses cause colds and upper respiratory tract infections in individuals with strong immune systems, they cause lower respiratory tract infections in immunocompromised individuals and in elder individuals (4).

The Betacoronavirus class includes severe acute respiratory syndrome (SARS) virus (SARS-CoV), Middle East respiratory syndrome (MERS) virus (MERS-CoV), and the COVID-19 causative agent SARS-CoV-2. Similar to SARS-CoV and MERS$\mathrm{CoV}$, SARS-CoV-2 attacks the lower respiratory system to cause viral pneumonia, but it may also affect the gastrointestinal system, heart, kidney, liver, and central nervous system leading to multiple organ failure. Mortality rates from SARS-CoV and MERS-CoV are $10 \%$ and $35 \%$, respectively. Current information shows that SARS-CoV-2 is more contagious than SARS-CoV. As with other respiratory pathogens, including flu and rhinovirus, transmission of SARS-CoV-2 is believed to occur through respiratory droplets from coughing and sneezing. Aerosol delivery also occurs when exposed to high aerosol concentrations over long periods of time in closed areas. Based on research from the first cases in Wuhan, it has been observed that the incubation period from the transmission of infection to the occurrence of symptoms can be up to 2 weeks.

The SARS-CoV-2 genome is packaged in a helical nucleocapsid surrounded by a lipid bilayer (6). Like other CoVs, it is sensitive to ultraviolet rays and heat. Also, these viruses can be effectively inactivated with lipid solvents including ether (75\%), ethanol, chlorine-containing disinfectants, peroxyacetic acid and chloroform, excluding chlorhexidine (4). The virus envelope contains at least three viral proteins called spike protein $(S)$, membrane protein $(\mathrm{M})$ and envelope protein $(\mathrm{E})$. While $\mathrm{M}$ and E proteins form the structure of the virus, the $S$ protein promotes the entrance of the virus into host cells (6).

Viral entry is based on a subtle interaction between the virus and the host cell. Infection begins with the interaction between host cell surface and $S$ proteins of virus. After initial contact with the host cell receptor, enveloped viruses must fuse their envelope with the host cell membrane to deliver their nucleocapsids to the cytoplasm. The $S$ protein plays a dual role in entry into the host cell by mediating receptor binding and membrane fusion (6).

The $S$ protein contains two subunits, $S 1$ and $S 2$. The $S 1$ subunit has a receptor binding domain (RBD) that interacts with the host cell receptor, angiotensin converting enzyme-2 (ACE-2), whereas the $\mathrm{S} 2$ subunit facilitates the fusion of the virus to the host cell to release genetic material into the cytoplasm to enable viral replication (7).

ACE-2 is a membrane-bound aminopeptidase that has a vital role in the cardiovascular system and immune system. ACE-2 has been identified as a functional receptor for $\mathrm{CoVs}$, including SARS-CoV and SARS-CoV-2. SARS-CoV-2 infection is triggered by the binding of the $S$ protein of the virus to ACE-2, which is highly expressed in the heart and lung cells' surfaces. SARS-CoV-2 mainly invades alveolar epithelial cells, causing life-threatening symptoms in respiratory systems (3). ACE-2 also regulates the protective mechanisms of the lungs. SARS-CoV-2 is also fatal as it blocks this protective mechanism (8). CryoEM structure analysis revealed that the binding affinity of the $S$ protein of SARS-CoV-2 to ACE-2 was approximately 10-20 times higher than that of the $S$ protein of SARS-CoV. Current information indicates that SARSCoV-2 is more transmissible/ contagious than SARS-CoV (5).

\section{Current Treatment of COVID-19}

There is an urgent need for effective medication and vaccine for COVID-19 to alleviate the threat posed by the disease on public health and the burden of countries on health systems (9). Most treatment options has been formed with previous experiences in treating SARS-CoV, MERS-CoV and other viral diseases. Currently, the most important management strategy for severe cases consists of mechanical ventilation, ICU admission and supportive care. According to the WHO guidelines, it is treated with supportive care such as bed rest, oxygen saturation, adequate nutrition, prevention of dehydration, preservation of electrolyte and acid-base balance, antibiotics and isolation of patients uncertain or diagnosed with COVID-19 (10). According to data compiled by Milken Institute, headquartered in California, USA, 167 potential drugs, therapies and medical tools for the treatment of COVID-19 are at the pre-clinical or clinical stage. Of these, 55 are antibiotics, 22 antivirals, 14 are cell-based, 5 are RNA-based drug candidates, 66 are immune-converting 
compounds, and 5 are medical devices such as blood purification filters and respiratory support devices (9). Drugs with previously known efficacy such as remdesivir, chloroquine, favipiravir and immune plasma therapy have been added to treatment protocols (10). In addition, vitamin C and ACE inhibitor supplementation to the treatment are discussed (9).

In order for a drug to be used in the treatment of a particular disease, a 4-stage clinical trials should be passed, each with the approval of the relevant national health authorities.

In phase I studies, drug candidate was tested on a small group of often healthy people (20 to 80 ) to judge its safety and side effects and to find the correct drug dosage.

Phase II studies aims to obtain preliminary data on whether the drug works in people who have a certain disease or condition while the safety studies, including short-term side effects are being continued.

In phase III studies the same procedure with phase II must be followed with a large number of patients. At this stage, if the safety and efficacy of the drug candidate is proven sufficiently, it gains the status of "new drug application" (NDA) and can be put on the market with the approval of the relevant health and trade institutions.

In phase IV studies, the possible adverse effects of the drug, which has been put on the market after the approval, on the wide user population are followed up and reported (9).

For the treatment of COVID-19, there is no cure with proven efficacy and safety that meets the approvel criteria. However, among the options evaluated for COVID-19 treatment, there are agents that inhibit viral replication, agents that bind directly to the virus and neutralizing antibodies, antibodies that target the host cell ACE-2 receptor or block S1, S2 and RBB (10). In this article, studies on vaccines and therapeutics developed through the ACE-2 and SARS-CoV-2 fusion mechanism were reviewed.

\section{Potential Treatment Approach for COVID-19}

There is no effective treatment for COVID-19 yet. Although the effectiveness of many antivirals available in the market for the treatment of the disease is evaluated, many new approaches are also considered. Viral fusion is the key step in the onset of SARS-CoV-2 infection. In this review, therapeutic approaches that may slow viral entry into cells and hence viral spread by preventing ACE-2-mediated entry of viruses are discussed. These approaches are listed in Table 1.

\section{Drugs and vaccines that prevent spike protein and ACE-2 fusion}

Based on the fact that ACE-2 is the SARS-CoV-2 receptor, the idea has arisen that a vaccine based on the $S 1$ subunit protein can be developed and large-scale vaccine can be produced using cell lines (8).

Vaccines are generally classified as inactive or live attenuated viruses, virus-like particles (VLP), viral vectors, protein-based, DNA-based or mRNA-based vaccines (8). Protein-based vaccines can include the full length the $S$ protein, $S 1$ subunit, RBD, and/ or the nucleocapsid of virus.

It may be necessary to use protein-based adjuvants or to fuse them with Fc unit. The most important feature of these formulations; high safety profile and their ability to stimulate cellular and humoral immune response. The developed formulations are currently in a preclinical study phase. VLP mimic the structure of the whole virus and can contain RBD, $\mathrm{M}$ and/or E proteins. These formulations are easy to manufacture because they can expressed in bactoviruses system. Also, VLP mimic the structure of the whole virus, unlike protein-based vaccines (11).

A study on recombinant vectors expressing the $S$ protein of SARS-CoV revealed that this protein is highly immunogenic and

Table 1. ACE-2 based potential treatment approaches for COVID-19

Virus-like particles

Drugs and vaccines that prevent spike protein and ACE-2 fusion

Drugs affecting the reninangitotensin-aldesteron-system

Excessive ACE-2 therapy
Protein-based vaccines

Neutralizing monoclonal antibodies

ACE-I and AT1R inhibitors

rhACE-2
RBD, $M$ and $E$ proteins.

Similar to viral structure.

Full length S protein, S1 subunit, $\mathrm{M}$ and/or $\mathrm{E}$ proteins.

targets S protein epitopes.

Its ability to reduce pulmonary inflammatory responses suggests that it may decrease mortality.

Treatment with ACE2 may slow viral entry into cells and hence viral spread.

ACE: Angiotensin converting enzyme, RBB: Receptor binding site, RBD: Receptor binding domain 
protective against SARS-CoV in hamsters. However, It didn't neutralized N, M and E proteins significantly (12). In addition, it has been reported that vaccines containing the subunit of $S$ protein achieve higher neutralizing antibody titres and provide better protection than others (5). Vaccination is the best option to prevent the spread of infectious diseases. Vaccine-induced humoral immune responses specifically involve the production of neutralizing antibodies. Currently, no vaccine has been licensed to prevent SARS-CoV-2 infection. Only a few promising vaccines for SARS-CoV have reached Phase I clinical trials, but vaccine development has been stopped due to the cessation of the SARS outbreak. SARS-CoV and SARS-CoV-2 bind to the same host cell receptor (ACE-2) and have similar disease pathogenesis. For this reason, it was thought that it could be treated with common neutralizing antibodies, albeit limited. Current approaches to the development of SARS-CoV-2 vaccines are mostly based on the methods used for the development of SARS-CoV vaccines (13).

$S$ protein plays an important role in developing immunity against SARS-CoV by stimulating neutralizing antibodies and $\mathrm{T}$ cells in the body. Therefore, it is believed that the full length or suitable fragment of the $S$ protein is the most promising candidate for developing vaccine against $\mathrm{CoVs}$.

It has been reported that other structural proteins do not affect the immunogenicity of the $S$ protein or its binding to the ACE2 receptor, which is a critical initiation step for the virus to reach the host cell. The ability of RBD in $S$ protein to induce neutralizing antibody is quite high. In addition, recombinant proteins containing $\mathrm{RBD}$ and recombinant vectors encoding RBD can be used for the development of effective SARS-CoV-2 vaccines (7). Current vaccine development studies for SARSCoV-2 are listed in Table 2.
Direct administration of monoclonal antibodies $(\mathrm{mAb})$ can play an effective role in treating SARS-CoV-2 infected individuals. It has been observed that patients recovering from SARS create strong neutralizing antibody responses. $S$ protein epitopes and functions could be targeted. With these antibodies to increase humoral protection against CoVs. RBD-specific neutralizing $\mathrm{mAbs}$ developed for SARS-CoV are thought to be able to provide cross-neutralization for SARS-CoV-2 due to similarity in RBD of both virus. Cross-neutralizing effect of $m A$ bs specific to SARS-CoV RBD can be evaluated for efficacy against SARS$\mathrm{CoV}-2$ (7).

The entry of SARS-CoV into the host cell continues with the formation of hexagonal helix regions by repeating heptad (HR1 and HR2), showing structural changes in the S protein S2 domain following the binding of the $S 1$ domain of the $S$ protein to a receptor. Studies have shown that peptides derived from the HR2 region can inhibit SARS-CoV entry. In one study, two recombinant proteins were designed with recombinant DNA technology, one containing two HR1 and one HR2 peptide (indicated by HR121), the other containing two HR2 and one HR1 peptide (designated HR212). These two proteins exhibited high inhibitory effect on the entry of HIV/SARS pseudovirus into the host cell with IC50 values of 4.13 and $0.95 \mu \mathrm{M}$, respectively. In addition, these proteins have low production costs and can be easily purified. These properties suggest that HR121 and HR212 may be potent inhibitors of SARS-CoV entry (14). This has led to the idea that it can be effective in the treatment of COVID-19.

The technique based on directly isolating the antibody and designing suitable antibodies without cloning the gene previously developed for HIV treatment is also used for SARS-CoV-2 in China. Since the virus can easily develop resistance in treatment

Table 2. Current vaccine development studies for SARS-CoV-2 [Adapted from reference (10)]

\begin{tabular}{|c|c|c|c|}
\hline Vaccine unit & Vaccine unit & Company & Progress \\
\hline Protein subunit & S protein & WRAIR/USAMRIID & Preclinical \\
\hline Protein subunit & $\begin{array}{l}\text { S protein } \\
\text { (Baculovirus production) }\end{array}$ & Sanofi Pasteur & Preclinical \\
\hline Protein subunit & $\begin{array}{l}\text { Full Length S protein, S1, } \\
\text { RBD, nucleocapsid } \\
\text { - formulated with adjuvants or } \\
\text { fused with fc }\end{array}$ & $\begin{array}{l}\text { (Novavax, Phase III) } \\
\text { recombinant S protein (Vaxine } \\
\text { Pty Ltd, Australia, Phase I) }\end{array}$ & Preclinical \\
\hline Protein subunit & Peptite & Vaxil bio & Preclinical \\
\hline
\end{tabular}


with a single antibody, different combinations of mAbs should be added to these formulations (15).

\section{Therapeutic Potential of Drugs Acting on the Renin- angiotensin-aldosteron-system}

The interaction sites between ACE-2 and SARS-CoV have been defined at the atomic level, and studies so far have shown that the same principles apply to the interactions between ACE- 2 and SARS-CoV-2. It was thought that by blocking these interaction sites with antibodies or small molecules, transfection of the virus could be prevented (8). Therefore, it has been suggested that ACE inhibitors such as lisinopril can be used (16).

In the lungs, activation of the local pulmonary Renin Angiotensin System (RAS) may affect the pathogenesis of lung injury by multiple mechanisms such as increased vascular permeability and alveolar epithelial cells. Angiotensin type-1 (AT1R) receptor activation provides RAS activation. It begins with renin, the starting enzyme of the pulmonary RAS activation cascade. Renin breaks down angiotensinogen, a globular protein, to produce angiotensin I (Ang I, a decapeptide hormone). ACE then converts Ang I to Ang II (Ang II, an octapeptide hormone). Ang II activates vasoactive effects by binding to angiotensin II type I (AT1) and type II (AT2) receptors. ACE-2 is an ACE homolog and plays an important role in balancing responses initiated from ACE. ACE-2 hydrolyzes Ang I to produce Ang- (1-9). ACE-2 also hydrolyzes Ang II to form Ang- (1-7), which binds to the G-protein coupled receptor MAS to antagonize most of the Ang II mediated effects. Generally, ACE-2 functions as a regulatory enzyme by decreasing native Ang II concentrations. In the lungs, RAS activity increases ACE and Ang II concentrations, and ACE2 activities begin to rise to regulate the balance of Ang II/Ang(1-7) levels. High Ang II levels increase vascular permeability, leading to pulmonary edema (16).

Therefore, angiotensin receptor blockers (ARBs) have the capacity to reduce inflammation and endothelial and epithelial dysfunction in many organs. ARBs preserve the integrity of the lung endothelial barrier, which is disrupted by acute injuries of the lung caused by viruses. There is substantial clinical evidence of direct effects of ARB therapy on protection of the lung associated with pneumonia, sepsis and influenza.

It was observed that the mortality rate was lower in patients treated with ARBs for cardiovascular diseases and later hospitalized for pneumonia. In studies conducted in rodents in cerebral malaria, which is caused by endothelial dysfunction, increased proinflammatory cytokine production, and increased coagulation and complement activation, ARB treatment has been observed to decrease mortality. In addition, treatment with ARBs appears to significantly reduce mortality during the Ebola epidemic in Africa, although these reports have not been fully confirmed (17).

In acute respiratory distress syndrome mouse models, ACE2 knockout mice exhibited more severe symptoms, while overexpression of ACE-2 had some protective effects. In SARS$\mathrm{CoV}$ infection of mice, it has been shown that both viral replication and viral $S$ protein selectively reduce ACE-2 rather than reducing ACE (18). In addition, SARS-CoV also causes the rapid down-regulation of ACE- 2 from the cell surface and the release of catalytically active ACE- 2 ectodomains. These results show that the balance between physiological ACE/ACE-2 and angiotensin II/angiotensin (1-7) is possibly disrupted by SARS$\mathrm{CoV}$ viral infection (16). Since SARS-CoV-2 binds to ACE-2, just like SARS-CoV, it is thought that this virus disrupts the RAS balance and causes exacerbation of pneumonia. Therefore, it is thought that ACEI and AT1R inhibitors may decrease SARS$\mathrm{CoV}-2$ induced pulmonary inflammatory responses and thus decrease mortality (7). There are many ongoing clinical studies in this context. In addition, there are literature suggesting that increasing the ACE-2 level of ARBs facilitates the binding of the SARS-CoV-2 virus to these regions, but the definitive information has not been obtained yet (17).

\section{Excessive Amounts of ACE-2 as a Therapeutic Agent}

Studies has begun on the idea that increasing ACE-2 activity by exogenous administration of ACE- 2 may also be beneficial in human diseases with pathologically high Ang-8. As a first step, pharmacokinetics, pharmacodynamics, safety and tolerability of recombinant ACE-2 (rhACE-2) in healthy volunteers were determined. rhACE-2 was administered intravenously to healthy human subjects in a randomized, double-blind, placebo-controlled, single-dose, dose-escalation study followed by an open-label multi-dose study. ACE-2 concentrations were determined by measuring ACE- 2 activity and ACE- 2 content in plasma samples. Concentrations of the angiotensin system effector peptides Ang1-8, Ang1-7 and Ang1-5 were determined using liquid chromatography-tandem mass spectrometry method. As a result, single rhACE-2 doses of 100-1,200 g/ $\mathrm{kg}$ were observed to have a dose-dependent increase in systemic exposure with biphasic elimination and a dose-independent terminal half-life (10 hours). In all single dose cohorts, Ang1-8 decreased within 30 minutes after infusion, Ang1-7 was either increased (100 and $200 \mathrm{lg} / \mathrm{kg}$ doses$)$, or decreased or unchanged $(400-1,200 \mathrm{lg} / \mathrm{kg}$ doses). Ang1-5 was transiently increased for all doses studied. Except for the lowest rhACE-2 dose, reduction in Ang1-8 levels lasted at least 24 hours. Repeated dosing ( $400 \mathrm{lg} / \mathrm{kg}$ for 3 or 6 days) resulted in only minimal ACE-2 accumulation and Ang1-8 levels could be suppressed over the entire administration period. As a result rhACE-2 administration was well tolerated by healthy human subjects. Despite marked changes in angiotensin system peptide concentrations, no cardiovascular effects were observed in healthy volunteers (19).

Khan et al. (20) reported the results of a phase II study examining the safety and efficacy of GSK2586881, a rhACE-2, in patients with acute respiratory syndrome. They have shown that the administration of a wide variety of GSK2586881 doses is safe without causing significant hemodynamic changes. The use of twice-daily infusion doses of GSK2586881 caused a rapid decrease in plasma Ang II levels and an increase in Ang 1-7 and Ang 1-5 levels, as well as a decrease in plasma interleukin-6 concentrations (20). Kuba et al. (18) showed that the $S$ protein of SARS-CoV binds to ACE-2 (but not ACE) in mice, 
causing severe lung injury. With the administration of ACE2 to the lungs, the virus is likely to bind to ACE-2, which is given excessively to the body, rather than to the body's ACE-2 receptors. In this case, ACE-2 receptors that provide hemeostasis of the lung will be able to continue their functions. Thus, treatment with a soluble form of ACE2 itself may exert dual functions: (1) slow viral entry into cells and hence viral spread and $(2)$ protect the lung from injury $(8,18)$. Based on these ideas, it was thought that exogenous administration of ACE- 2 could be therapeutic, and a clinical study was initiated to investigate the efficacy of rhACE-2 in soluble form for SARS-CoV-2. An openlabel, controlled, randomized, pilot study was designed to obtain biological, physiological and clinical data about the treatment of COVID-19 patients with rhACE-2.

It is aimed to examine all biological, physiological and clinical data to determine whether there is any signal of efficacy requiring a Phase $2 \mathrm{~B}$ trial or to determine toxic effects that would prevent such treatment. Efficacy analysis will be performed for patients receiving at least 4 doses of therapy, and safety analysis will be performed for all patients receiving at least one dose of treatment. It is expected that there will be at least 12 patients in each group. For 7 days, the experimental group will be treated $0.4 \mathrm{mg} / \mathrm{kg}$ of $\mathrm{rhACE}-2$ and standard care, while the control group will be treated with only standard care (21). The result of the research will provide very important data for the treatment of COVID-19.

\section{Nanoparticular Drug Carrier Systems}

Drug delivery systems have several advantages over traditional drug forms. With these systems, the active substance can be targeted to the desired body part, thus minimizing or side effects on vital tissues. The accumulation of therapeutic compounds at the target site can be increased, resulting in more effective treatment at lower doses. This modern form of treatment is particularly important when there is a discrepancy between the dose or concentration of a drug and its therapeutic consequences or toxic effects. Cell specific targeting can be accomplished by entrapping drug in designed carriers. Various nanostructures have been tested as drug delivery systems, including liposomes, polymers, dendrimers, silicon or carbon materials, and magnetic nanoparticles (22).

Lipid or polymer-based nanoparticular drug delivery systems can be designed to improve the pharmacological and therapeutic properties of parenterally administered drugs. These particulate nano-systems have overcome the problems that prevent the clinical applications of some anticancer and antifungal drugs and have been approved for clinical use. These include lipid-based carriers such as liposomes and micelles, emulsions and lipiddrug complexes; there are also various ligand targeted products such as polymer-drug conjugates, polymer microspheres and immunoconjugates (23).

Drugs evaluated for the treatment of COVID-19 need to be administered in a drug delivery system, especially in the treatment of this disease, which causes lung involvement. Liposomes can be targeted actively or passively to the lungs (24).
In addition, liposomes have been used as a trap in the treatment of viral diseases because of their cell-like properties $(25,26)$. Liposomes could be used in COVID-19 treatment due to their biocompatibility, targeting to the region and their ability to create a trap structure.

\section{Liposomes}

Liposomes are generally defined as spherical vesicles with particle sizes ranging from $30 \mathrm{~nm}$ to several micrometers. They consist of a lipid bilayer surrounding the aqueous units, with the polar head groups oriented towards the inner and outer aqueous phases. These vesicles, which have one or more phospholipid bilayer membranes, may carry aqueous or lipid drugs. Liposomes were first described in the mid-1960s. Liposomes are very useful markers and tools in many disciplines such as mathematics, theoretical physics, biophysics, chemistry, colloid science, biochemistry and biology. Due to their biocompatibility, biodegradability, low toxicity, and ability to entrap both hydrophilic and lipophilic drugs, many studies have been conducted on liposomes to reduce drug toxicity and/or targeting systems. Liposomes as drug carriers has some advantages such as increased solubility of lipophilic and amphiphilic drugs, passive targeting to immune system cells, especially mononuclear phagocytic system cells, ability to deliver systemically or locally of drugs, improved bioavailability of hydrophilic molecules, and improved penetration into tissues (27).

Due to recent advances in liposome technology, many liposomebased drug formulations have been approved for clinical use. Entrapment of drugs in liposomes has provided the opportunity to improve the therapeutic effect of various agents, mainly through changing their biodistribution (28).

Research into the interaction between pathogens and liposomes began after the first mechanical studies discoverd by Bangham et al. (29) that streptolysin-S can regulate the cationic permeability of multilayer liposomes. Researchers have used liposomes as pathogen substrates. Liposome microarrays can be used for ultrasensitive detection of various types of pathogens, including viruses, bacteria and fungi. These cell membrane mimics, formed with functional ligands as well as synthetic lipids, can promote the formation of pathogen-liposome complexes that effectively increase detection sensitivity in various electrochemical and immunological assays. Another example that utilizes the liposome-pathogen interaction is direct inhibition of the pathogen infection with liposomes. Pathogens can be trapped and retained by liposomes that mimic the cell membrane, preventing them from attacking their cellular targets. In viral and bacterial infection models, treatment with functionalized liposomes has been shown to increase subject survival and reduce overall infection. Engineered liposomes have also been used as a secondary therapeutic to supplement conventional anti-infective drugs. Systemic administration of nanoscale liposomes with penicillin effectively protected animals from septicemia caused by $S$. pneumoniae and $S$. aureus. In addition, researchers have used liposome-pathogen interaction for drug release triggered by infection. Surface engineering of liposomes with specific 
molecule may further increase the applicability of synthetic liposomes against infectious diseases $(25,26)$.

Lactoferrin (LF) has strong antiviral activity against RNA and DNA viruses, including human immunodeficiency virus, zika virus, hepatitis $\mathrm{C}$, cytomegalovirus, herpes simplex virus, and human papilloma virus. Serrano et al. (30) designed a prospective observational study in 75 patients with positive immunoglobulin (Ig) M/IgG tests and typical COVID-19 symptoms. In order to provide maximum anti-inflammatory and immunomodulatory effect and to protect LF from the harmful effects of enzymes and acids in the stomach, a formula encapsulated in LF phosphatidylcholine-based liposomes has been used. The patients were isolated at home and examined remotely twice a day for 10 days and followed for up to 1 month. As a dietary supplement, liposomal bovine LF (LLF) nutritional syrup (32 $\mathrm{mg} \mathrm{LF} / 10 \mathrm{ml}$ $+12 \mathrm{mg}$ vitamin C) was administered orally at 4 to 6 doses per day for 10 days. In addition, zinc solution was supplemented orally at a dose of $10 \mathrm{mg} / 10 \mathrm{~mL}$ two or three times a day. The control group received only oral LLF. In addition, half of the LLF dose given to patients' was orally administered to the patients relatives. The treatment provided a complete and rapid recovery in all patients (100\%) within the first 4-5 days. In addition, COVID-19 findings were not diagnosed in the relatives of the patients. As a result of the study, the researchers concluded that LLF potentially prevented and treated COVID-19 infection (30).

It has been demonstrated in vitro studies that hydroxychloroquine (HCQ), an antimalarial and anti-inflammatory drug, inhibits SARS-CoV-2 infection and its therapeutic efficacy has been evaluated with clinical studies. In order to show its antiviral activity in vivo, it must be present in the lung at a concentration of approximately $6.7 \mu \mathrm{g} / \mathrm{mL}$. However, this concentration may not be achieved with the currently recommended oral dosing regimen. Administration of high doses of HCQ to achieve the desired lung concentration raises concerns about systemic toxicity, including cardiotoxicity. It has been proven that inhaled liposomal formulations can reach effective concentrations in the lung and show efficacy at lower doses compared to systemic administration.

Tai, Wu (31) demonstrated the pharmacokinetics of inhaled liposomal HCQ in a rat model. It has been observed that respirable liposomal HCQ achieves the desired antiviral efficacy by administering it less frequently and at low doses. Therefore, the hypothesis that the formulation could be a potential treatment option in COVID-19 was supported (31).

\section{Targeting Liposomes to the Lungs}

Liposomes are widely used drug carriers by inhalation due to their safety and ability to provide controlled drug release in the lung. These carriers can entrap a wide variety of therapeutic molecules for delivery to peripheral airways in large volumes using medical nebulizers (31).

Drugs investigated for pulmonary administration via liposomes include anticancer agents (ara-C), antimicrobials (enviroxime, amikacin, pentamidine), peptides (glutathione), enzymes (superoxide dismutase), antiasthmatic and antiallergic compounds (metaproterensteol, salbutamol, sodium bichrome, corticosteroids) and promising developments such as pulmonary delivery of immunomodulators, antiviral agents and gene structures (cystic fibrosis, $\alpha 1$-antitrypsin gene) are also discussed. Finally, pulmonary deposition and kinetics of drugs administered in the form of liposomal aerosols and targeting strategies for selectively delivering drugs to infected or impaired phagocytic (alveolar macrophages) and non-phagocytic (epithelial) cells in the lung are studied (32).

Liposomes could be use to reduce some of the problems in traditional aerosol administration, such as facilitating intracellular delivery of drugs, particularly to alveolar macrophages. As a result, liposomes prevent local irritation of lung tissue and reduce pulmonary toxicity; prolonging local therapeutic drug levels. So it can produce high intracellular drug concentrations in infected alveolar macrophages (32).

With passive targeting, the liposomes are delivered to the targeted areas. by controlling the size of the particles (33).

Generally, liposomes with a particle size greater than $5 \mu \mathrm{m}$ can be passively captured by the vascular network of the lung to achieve lung targeting effect (34). Pulmonary delivery of drugs has disadvantages such as; the need for training for patients to coordinate the breathing of aerosols, the rapid absorption of most drugs, frequent dosing that often causes systemic side effects, poor water solubility of drugs that can cause local irritation and inflammation of the airways or prevent the use of aerosols completely and poor cytosolic penetration of the drug (32).

In addition, some unfavorable conditions were observed in the administration of nanoparticles to the pulmonary system via inhaler. For example, some nanoparticles can also be localized in organs distal to the respiratory tract, which can initiate the interaction of nanoparticles with subcellular structures following endocytosis by different target cells (34).

The intravenous route is a common method of delivering higher doses of drugs into the body. Many drugs loaded into carrier systems such as microspheres, microcapsules, liposomes and nanoparticles can be delivered directly to the circulation, avoiding first pass metabolism, and with the aid of these drug carriers, drugs can be delivered intravenously to the lungs. In addition, these systems can increase the drug concentration in the lung to therapeutic level after intravenous administration while reducing its distribution to other organs or tissues. At the same time, these systems can control drug release into the lungs and extend the duration of action to improve the therapeutic effect and patient compliance. Pulmonary administration in aerosol form is an interesting area of research for local or systemic delivery of the drug. However, most drugs should be applied at least three to four times a day due to their short half life.

Another disadvantage is that inhaled drugs cannot be easily delivered to the spesific area in the lungs due to the blocking of the airways from inflammation or mucus plugs, which can lead to more accumulation in the airways (34). 


\section{Result}

With the information obtained from SARS and MERS outbreaks, it is known that an $S$ protein-based vaccine could provide the required immunity. In $S$ protein-based vaccine and drug development studies, the principle of blocking affinity of the $S$ protein to ACE-2 has been discussed.

It has been suggested that ARBs prevent lung damage and reduce mortality due to their lung protective effect. However, since ARBs increase the rate of ACE-2, there are concerns that SARS-CoV-2 entry to host cells could increase. However, ACE-2 regulation is a very complex mechanism, and its direct positive or negative effect on SARS-CoV-2 viral spread has not yet been proven. The current clinical data mostly includes a few patients and there is no control group, so it is not possible to make a scientifically definitive result.

Developing $S$ protein-based vaccine and treatment options by blocking the ACE-2 receptor, and proving its efficacy needs long time. However, the competitive binding of ACE-2, which is in the body's own hemostasis, to viruses after administration seems to be both a simple and effective treatment option. The results of the clinical studies conducted in this context are thought to be promising.

Drug delivery systems have several advantages over traditional drug forms. With these systems, the active substance could be targeted to the desired area, thus increasing its effect on vital tissues and minimizing side effects. Lipid or polymer-based nanoparticular drug delivery systems could be designed to improve the therapeutic effects of parenterally administered drugs.

Drugs evaluated for the treatment of COVID-19 need to be administered in a drug delivery system to reach therapeutic concentrations. Liposomes can be targted actively or passively to the lungs. In addition, liposomes have been used as a trap in the treatment of viral diseases because of their cell-like properties.

In summary, no corona virus-specific therapeutic agent, monoclonal antibodies, or vaccine has been approved. Thus, there is an urgent need for effective medication and vaccine for COVID-19 disease to limit the transmission in the community. Most treatment options for COVID-19 taken from previous experiences in treating SARS-CoV, MERS CoV, and other viral diseases. Due to the fact that SARS-CoV-2 enters the host cell through ACE-2, the basic mechanism of the drugs developed to block the affinity between ACE-2 and the $S$ protein is mentioned in this review. In addition, liposomes based, potential drug development studies in the treatment of COVID-19 was mentioned.

Peer-review: Externally peer reviewed.

\section{Authorship Contributions}

Data Collection or Processing: S.A., T.Ç., Analysis or Interpretation: S.A., T.Ç., Literature Search: S.A., T.Ç., Writing: S.A., T.Ç.
Conflict of Interest: No conflict of interest was declared by the authors.

Financial Disclosure: The authors declared that this study received no financial support.

\section{References}

1. Akbabaa M, Kurtb B, Nazlıcanc E. A New Coronavirus Outbreak: MERS-CoV. Turk J Public Health 2014;12:217-27.

2. KLİMUD. Yeni Koronavirüs ("Novel Coronavirus" 2019-nCoV) KLİMUD Klinik Viroloji Çalışma Grubu Bilgi Notu 2020. Available from: https:/www.klimud.org/content/779/yeni-koronavirus-novelcoronavirus-2019-ncov---klimud-klinik-viroloji-calisma-grububilgi-notu-.

3. Zheng Y-Y, Ma Y-T, Zhang J-Y, Xie X. COVID-19 and the cardiovascular system. Nat Rev Cardiol 2020;17:259-60.

4. Cascella M, Rajnik M, Cuomo A, Dulebohn SC, Di Napoli R. Features, evaluation and treatment coronavirus (COVID-19). Statpearls: StatPearls Publishing; 2020.

5. Liu C, Zhou Q, Li Y, Garner LV, Watkins SP, Carter LJ, et al. Research and development on therapeutic agents and vaccines for COVID-19 and related human coronavirus diseases. ACS Cent Sci 2020;6:315-31.

6. Belouzard S, Millet JK, Licitra BN, Whittaker GR. Mechanisms of coronavirus cell entry mediated by the viral spike protein. Viruses 2012;4:1011-33.

7. Dhama K, Sharun K, Tiwari R, Dadar M, Malik YS, Singh KP, et al. COVID-19, an emerging coronavirus infection: advances and prospects in designing and developing vaccines, immunotherapeutics, and therapeutics. Hum Vaccin Immunother 2020;16:1232-8.

8. Zhang H, Penninger JM, Li Y, Zhong N, Slutsky AS. Angiotensinconverting enzyme 2 (ACE2) as a SARS-CoV-2 receptor: molecular mechanisms and potential therapeutic target. Intensive Care Med 2020;46:586-90.

9. FIP. COVID-19: Klinik Bilgi ve Tedavi Kılavuzları. 2020. Available from: https://www.fip.org/file/4825

10. Belete TM. A review on Promising vaccine development progress for COVID-19 disease. Vacunas. Amsterdam: Elseiver; 2020.

11. Vaduganathan M, Vardeny O, Michel T, McMurray JJ, Pfeffer MA, Solomon SD. Renin-angiotensin-aldosterone system inhibitors in patients with Covid-19. N Engl J Med 2020;382:1653-9.

12. Salvatori G, Luberto L, Maffei M, Aurisicchio L, Roscilli G, Palombo F, et al. SARS-CoV-2 SPIKE PROTEIN: an optimal immunological target for vaccines. J Transl Med 2020;18:1-3.

13. Shih H-I, Wu C-J, Tu Y-F, Chi C-Y. Fighting COVID-19: A quick review of diagnoses, therapies, and vaccines. Biomed J 2020;43:3514.

14. Ni L, Zhu J, Zhang J, Yan M, Gao GF, Tien P. Design of recombinant protein-based SARS-CoV entry inhibitors targeting the heptadrepeat regions of the spike protein S2 domain. Biochem Biophys Res Commun 2005;330:39-45.

15. Sempowski GD, Saunders KO, Acharya P, Wiehe KJ, Haynes BF. Pandemic preparedness: developing vaccines and therapeutic antibodies for COVID-19. Cell 2020;181:1458-63. 
16. Wu Y. Compensation of ACE2 function for possible clinical management of 2019-nCoV-induced acute lung injury. Virol Sin 2020;35:256-8.

17. Saavedra JM. Angiotensin receptor blockers and COVID-19. Pharmacol Res 2020;156:104832. doi: 10.1016/j.phrs.2020.104832. PubMed PMID: 32304747; PubMed Central PMCID: PMCPMC7158830.

18. Kuba K, Imai Y, Rao S, Gao H, Guo F, Guan B, et al. A crucial role of angiotensin converting enzyme 2 (ACE2) in SARS coronavirusinduced lung injury. Nat Med 2005;11:875-9.

19. Haschke M, Schuster M, Poglitsch M, Loibner H, Salzberg M, Bruggisser $\mathrm{M}$, et al. Pharmacokinetics and pharmacodynamics of recombinant human angiotensin-converting enzyme 2 in healthy human subjects. Clin Pharmacokinet 2013;52:783-92.

20. Khan A, Benthin C, Zeno B, Albertson TE, Boyd J, Christie JD, et al. A pilot clinical trial of recombinant human angiotensin-converting enzyme 2 in acute respiratory distress syndrome. Critical Care 2017;21:1-9.

21. Yimin L. Recombinant Human Angiotensin-converting Enzyme 2 (rhACE2) as a Treatment for Patients With COVID-19 2020. Available from: https://clinicaltrials.gov/ct2/show/study/ NCT04287686.

22. Wilczewska AZ, Niemirowicz K, Markiewicz KH, Car H. Nanoparticles as drug delivery systems. Pharmacol Rep 2012;64:102037.

23. Allen TM, Cullis PR. Drug Delivery Systems: Entering the Mainstream. Science 2004;303:1818-22.

24. Chono S, Fukuchi R, Seki T, Morimoto K. Aerosolized liposomes with dipalmitoyl phosphatidylcholine enhance pulmonary insulin delivery. J Control Release 2009;137:104-9.
25. Rao L, Tian R, Chen X. Cell-membrane-mimicking nanodecoys against infectious diseases. ACS Nano 2020;14:2569-74.

26. Hendricks GL, Velazquez L, Pham S, Qaisar N, Delaney JC, Viswanathan K, et al. Heparin octasaccharide decoy liposomes inhibit replication of multiple viruses. Antiviral Res 2015;116:34-44.

27. Akbarzadeh A, Rezaei-Sadabady R, Davaran S, Joo SW, Zarghami N, Hanifehpour Y, et al. Liposome: classification, preparation, and applications. Nanoscale Res Lett 2013;8:102.

28. Mansoori Agrawal MA, Jawade S, Khan S, M I. A review on liposome. Int J Adv Res Pharm Bio Sci 2012;2:453.

29. Bangham A, Standish M, Weissmann G. The action of steroids and streptolysin $S$ on the permeability of phospholipid structures to cations. J Mol Biol 1965;13:253-IN28.

30. Serrano G, Kochergina I, Albors A, Diaz E, Oroval M, Hueso G, et al. Liposomal lactoferrin as potential preventative and cure for COVID-19. Int J Res Health Sci 2020;8:8-15.

31. Elhissi A. Liposomes for pulmonary drug delivery: the role of formulation and inhalation device design. Curr Pharm Des 2017;23:362-72.

32. Schreier H, Gonzalez-Rothi RJ, Stecenko AA. Pulmonary delivery of liposomes. J Control Release 1993;24:209-23.

33. Tüylek Z. İlaç Taşıyıcı Nanosistemler. Arşiv Kaynak Tarama Derg 28:184-92.

34. Wei Y, Zhao L. Passive lung-targeted drug delivery systems via intravenous administration. Pharm Dev Technol 2014;19:129-36. 